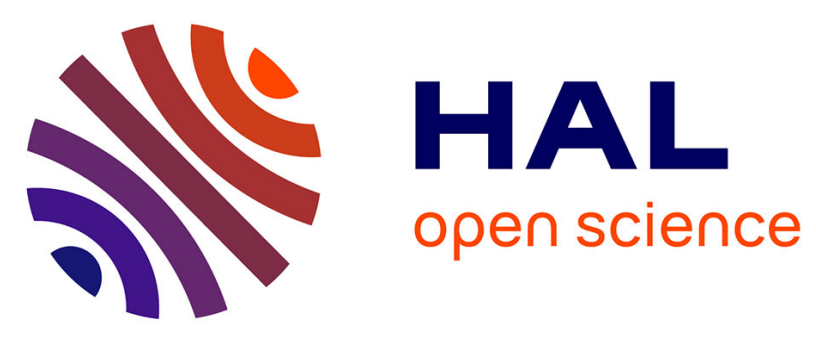

\title{
Interlaboratory quality control of total HIV-1 DNA load measurement for multicenter reservoir studies
}

Pierre Gantner, Adeline Mélard, Florence Damond, Constance Delaugerre, Julia Dina, Marie Gueudin, Anne Maillard, Karine Sandres-Sauné, Audrey Rodallec, Edouard Tuaillon, et al.

\section{To cite this version:}

Pierre Gantner, Adeline Mélard, Florence Damond, Constance Delaugerre, Julia Dina, et al.. Interlaboratory quality control of total HIV-1 DNA load measurement for multicenter reservoir studies. Journal of Medical Virology, 2017, 89 (11), pp.2047-2050. 10.1002/jmv.24874 • hal-01760708

\section{HAL Id: hal-01760708 https://hal.science/hal-01760708}

Submitted on 8 Jan 2019

HAL is a multi-disciplinary open access archive for the deposit and dissemination of scientific research documents, whether they are published or not. The documents may come from teaching and research institutions in France or abroad, or from public or private research centers.
L'archive ouverte pluridisciplinaire $\mathbf{H A L}$, est destinée au dépôt et à la diffusion de documents scientifiques de niveau recherche, publiés ou non, émanant des établissements d'enseignement et de recherche français ou étrangers, des laboratoires publics ou privés. 


\title{
Interlaboratory quality control of total HIV-1 DNA load measurement for multicenter reservoir studies
}

\author{
Pierre Gantner ${ }^{1} \quad$ Adeline Mélard $^{2} \quad$ Florence Damond $^{3}$ \\ Constance Delaugerre $^{4} \quad$ Julia Dina $^{5} \quad$ Marie Gueudin $^{6}$ \\ Anne Maillard ${ }^{7} \quad$ Karine Sauné $^{8} \quad$ Audrey Rodallec $^{9}$ \\ Edouard Tuaillon ${ }^{10}$ Jean-Christophe Plantier ${ }^{6}$ \\ Christine Rouzioux 2,11 Véronique Avettand-Fenoel 2,11 \\ on behalf of the ANRS-AC11 Quantification Working Group
}

\footnotetext{
1 Laboratoire de Virologie, Hôpitaux Universitaires de Strasbourg, Strasbourg, France

2 Université Paris-Descartes, Sorbonne Paris Cité, Faculté de Médecine, Paris, France

3 INSERM, IAME, UMR, Université Paris Diderot, Sorbonne Paris Cité, AP-HP, Hôpital Bichat-Claude Bernard, Laboratoire de Virologie, Paris, France

${ }^{4}$ Laboratoire de Virologie, AP-HP, Hôpital Saint-Louis, Paris, France

${ }^{5}$ Normandie Univ, UNICAEN, U2RM, Department of Virology, University Hospital, Caen, France

${ }^{6}$ Laboratoire de Virologie, Hôpital Charles Nicolle, CHU de Rouen, Rouen, GRAM, Faculté de Médecine-Pharmacie, Institut de Recherche et d'Innovation en Biomédecine, Université de Rouen, Rouen, France

${ }^{7}$ Laboratoire de Virologie Hôpital Pontchaillou, Rennes, France

${ }^{8}$ INSERM, Toulouse, France Université de Toulouse, Université Paul Sabatier, CPTP, Toulouse, France

${ }^{9}$ Laboratoire de Virologie, CHU Hôtel Dieu Nantes, France

10 Département de Bactériologie-Virologie, CHU de Montpellier, Université Montpellier 1/Inserm UMR, Montpellier, France

11 AP-HP, Hôpital Necker Enfants Malades, Laboratoire de Virologie, Paris, France

Correspondence

Véronique Avettand-Fenoel, AP-HP, Hôpital

Necker Enfants Malades, Laboratoire de

Virologie, CHU Necker, EA 7327 Université

Paris Descartes, 149 rue de Sèvres 75015 Paris,

KEYWORDS

France.

HIV-1 DNA, interlaboratory quality control, quantification

Email: veronique.avettand@aphp.fr

Funding information

Agence Nationale de Recherches sur le Sida et

les Hepatites Virales
}

Background: Viral reservoirs represent an important barrier to HIV cure. Accurate markers of HIV reservoirs are needed to develop multicenter studies. The aim of this multicenter quality control $(\mathrm{QC})$ was to evaluate the inter-laboratory reproducibility of total HIV-1-DNA quantification.

Methods: Ten laboratories of the ANRS-AC11 working group participated by quantifying HIV-DNA with a real-time qPCR assay (Biocentric) in four samples (QCMD).

Results: Good reproducibility was found between laboratories (standard deviation $\leq 0.2 \log _{10}$ copies $/ 10^{6} \quad \mathrm{PBMC}$ ) for the three positive $\mathrm{QC}$ that were correctly classified by each laboratory $(\mathrm{QC} 1<\mathrm{QC} 2<\mathrm{QC3})$.

Conclusions: Results of this QC validate the feasibility of multicenter studies using this standardized assay. 
Several home-made HIV-1 DNA quantification assays by PCR have

The ultimate treatment goal in HIV infection would be to eradicate the virus from its reservoirs, which are the main obstacle to curative therapy. ${ }^{1}$ To further study these reservoirs and to evaluate new cure strategies, several markers have been propose $e^{2}{ }^{4}$ but none has been evaluated for using in multicenter clinical studies. Among them, total cell-associated HIV-1 DNA presents the advantage to be feasible within large series of samples and permits longitudinal studies in clinical trials (OPTIPRIM, SPARTAC. . 4). ${ }^{-8}$ This biomarker has been widely used in both adult ${ }^{4-6,9}$ and pediatric ${ }^{4,10-11}$ cohorts. HIV-DNA load correlates with values obtained in the quantitative viral outgrowth assay. It provides useful information at different stages of the infection, irrespective of combined antiretroviral therapy, and with a variety of clinical samples (blood, rectal mucosa, breast milk, and semen).,12-13 Indeed, it has independent predictive value for progression to AIDS and death. ${ }^{4}$ Total HIV-1 DNA load in peripheral blood mononuclear cells (PBMC) correlates with biomarkers of inflammation and immune activation ${ }^{4,14}$ and residual plasma viremia during antiretroviral therapy. ${ }^{4,15}$ Total HIV-1 DNA load could be an accurate, clinically relevant marker for therapeutic decision-making. ${ }^{4}$ For example, some treatment de-escalation may not be appropriate for patients with high HIV-1 DNA levels, as stated in recent French guidelines. Baseline HIV-1 DNA levels might prove helpful for choosing patients who will be the best candidates to some therapeutic strategies. ${ }^{4}$ It might also prove useful for estimating HIV-1 reservoir to evaluate therapeutic strategies in multicenter trials. ${ }^{4}$ Finally, HIV-1 DNA can provide useful information, along with other markers, for HIV cure research. ${ }^{16-17}$

been used worldwide with different regions amplified and using various standards for quantification and various units, ${ }^{3,7,18-19}$ making difficult comparisons between studies. One real-time qPCR LTR HIV-1 DNA assay has been developed by the AC11 working group of the Agence Nationale de Recherches sur le SIDA et les hépatites virales (ANRS). This assay is now commercialized (Generic HIV DNA CELL, Biocentric, Bandol, France) and available for the scientific community'?

In the current context of therapeutic trials to reduce the HIV reservoir, it is essential to be able to develop multicenter studies. The aim of this national multicenter quality control was to evaluate the interlaboratory reproducibility of total HIV-1 DNA quantification in ten French laboratories using the same assay (Generic HIV DNA CELL, Biocentric).

\section{MATERIAL AND METHODS}

Ten laboratories of the AC11 Viral Quantification Working Group of ANRS participated in the qualitative HIV-1 DNA international QCMD quality control (www.qcmd.org/) in 2016. Four coded samples of freeze-dried PBMC pellets were used as the blind test panel and sent to each laboratory. It contained three samples (QC1, QC2, QC3) with HIV-1-infected PBMC, and one (QC4) with PBMC from an uninfected individual. QCMD indicated that $Q C 1, Q C 2$, and $Q C 3$ were obtained by dilutions of the same sample. Cell-associated HIV-1 DNA was searched and quantified by real-time PCR with the same Generic HIV DNA CELL assay kit (Biocentric) in the ten laboratories. The performances of this assay have been described previously. Notably the $95 \%$ and $50 \%$ detection thresholds for the assay were set at six and

TABLE 1 Procedural characteristics used in the ten laboratories and HIV-1 DNA loads obtained for the quality controls

\begin{tabular}{|c|c|c|c|c|c|c|c|}
\hline & \multicolumn{3}{|l|}{ Procedural characteristics } & \multicolumn{4}{|c|}{$\begin{array}{l}\text { HIV-1 DNA load (copies } / 10^{6} \text { PBMC) } \\
\log _{10} \text { copies } / 10^{6} \text { PBMC }\end{array}$} \\
\hline & Extraction method & $\begin{array}{l}\text { Method to } \\
\text { determine } \\
\text { the total DNA } \\
\text { concentration }\end{array}$ & Thermocycler & QC1 & QC2 & QC3 & QC4 \\
\hline Lab 1 & Automatic Qiagen (Qiasymphony) & Albumin qPCR & $\mathrm{ABI} 7500$ & (110) 2,0 & (626) 2,8 & $(1232) 3,1$ & ND \\
\hline Lab 3 & Manuel Qiagen (Qiamp DNA Blood) & Nanodrop & CFX96 & (181) 2,3 & (746) 2,9 & (2371) 3,4 & ND \\
\hline Lab 4 & Automatic Qiagen (EZ1 Advanced XL) & Nanodrop & SmartCycler & (102) 2,0 & (352) 2,5 & (1935) 3,3 & ND \\
\hline Lab 5 & Manuel Qiagen (Qiamp DNA Blood) & Nanodrop & StepOnePlus & (138) 2,1 & (706) 2,9 & (4197) 3,6 & ND \\
\hline Lab 6 & Automatic Qiagen (Qiasymphony) & Nanodrop & Rotorgene Q6 plex & (172) 2,2 & (667) 2,8 & $(3000) 3,5$ & ND \\
\hline Lab 10 & $\begin{array}{l}\text { Manuel Macherey-Nagel } \\
\text { (Nucleospin Blood) }\end{array}$ & Nanodrop & LC 480 & (49) 1,7 & (550) 2,7 & (1530) 3,2 & ND \\
\hline \multicolumn{4}{|l|}{ Median } & (110) 2,0 & (647) 2,8 & (2451) 3,4 & \\
\hline \multicolumn{4}{|c|}{ Standard deviation } & 0.2 & 0.2 & 0.2 & \\
\hline
\end{tabular}

ND, not detected. 
three copies/PCR, that is, 40 and 20 copies $/ 10{ }^{6}$ cells, respectively (1.6 and $1.3 \mathrm{log}$ ), when studying $1 \mu \mathrm{g}$ total DNA per PCR ${ }^{17}$ All laboratories obtained a good quality score of 0 with the qualitative analysis performed by the QCMD staff. So we decided to collect quantitative results to analyze inter-laboratories reproducibility.

DNA extraction procedure consisted of the automated Qiagen method (Courtaboeuf, France) in six laboratories, the manual QIAamp DNA minikit (Qiagen) in three laboratories, and the manual NucleoSpin Blood kit (Macherey-Nagel, Hoerdt, France) in one laboratory (Table 1). The final eluate volume ranged from 50 to $100 \mu \mathrm{L}$. The total DNA concentration was determined by fluorescence reading at $260 \mathrm{~nm}$ by the Nanodrop method (Labtech, Ringmer, UK) in eight laboratories, and by concurrently amplifying a housekeeping gene by real-time PCR in two laboratories (Table 1). In the Generic HIV DNA CELL kits, the 8 E5 cell line was used as standard for HIV-1 DNA quantification. Following the manufacturer's instructions, four dilutions of an extract of $8 \mathrm{E} 5$ cells were performed in order to deposit 6000 copies/PCR, 600 copies/PCR, 60 copies/PCR, and 6 copies/PCR. Quantitative results were normalized in number of copies per million cells as described previously. ${ }^{7}$ Quantitative data reported by the 10 laboratories in Logo $_{0}$ copies/million cells were then compared. Logs were used as usually performed for real-time PCR assays and as discussed by Kotton ef?al. Median and standard deviation were calculated for each positive sample of the quality control (QC1, QC2, QC3).

\section{RESULTS}

None of the 10 laboratories obtained a positive result with the negative sample (QC4).

Assay performance was analyzed with the three samples of HIV-1-infected PBMC (QC1, QC2, QC3). All three samples were positive and measurable in all 10 laboratories, with the exception of QC1, which was detected but lower than the quantification threshold (70 copies/million PBMC) in one laboratory owing to unsuccessful QIAcube extraction $(<2 \mu \mathrm{g} / \mathrm{mL})$.

The ranges were 1.7-2.3 $\log _{0}$ copies $/ 10^{6} \mathrm{PBMC}$ for $\mathrm{QC} 1,2.5-3.1$ $\log _{10}$ copies $/ 10^{6}$ PBMC for QC2, and 3.1-3.7 $\log _{10}$ copies $/ 10^{6}$ PBMC

for QC3 (Fig. 1A). The median values and standard deviations (SD) were $2.0 \pm 0.2 \log _{10}$ copies $/ 10^{6} \mathrm{PBMC}$ for QC1, $2.8 \pm 0.2 \log _{0}$ for $\mathrm{QC} 2$, and $3.4 \pm 0.2 \log _{10}$ for $Q C 3$, and a $95 \%$ confidence interval of $0.12 \log$ for each QC. There was no noteworthy influence of the HIV-1 DNA level on the dispersal of values obtained in the 10 laboratories. The results of the ten laboratories showed that the three positive quality controls were correctly classified by each of them: $Q C 1<Q C 2<Q C 3$. The study of variations of HIV-DNA loads between laboratories showed that the load for each control quality was comprised in the range (median -0.3 log; median $+0.3 \mathrm{log}$ ) for each laboratory (Fig. 1B).

Noteworthy, the 10 laboratories quantified HIV-DNA with one of three different batches of the Generic HIV DNA CELL assay kit. The results were similar regardless of the batch used. Despite the use of different extraction methods and the different amounts of DNA analyzed per well (between 0.1 and $1 \mu \mathrm{g}$ of DNA per well, depending
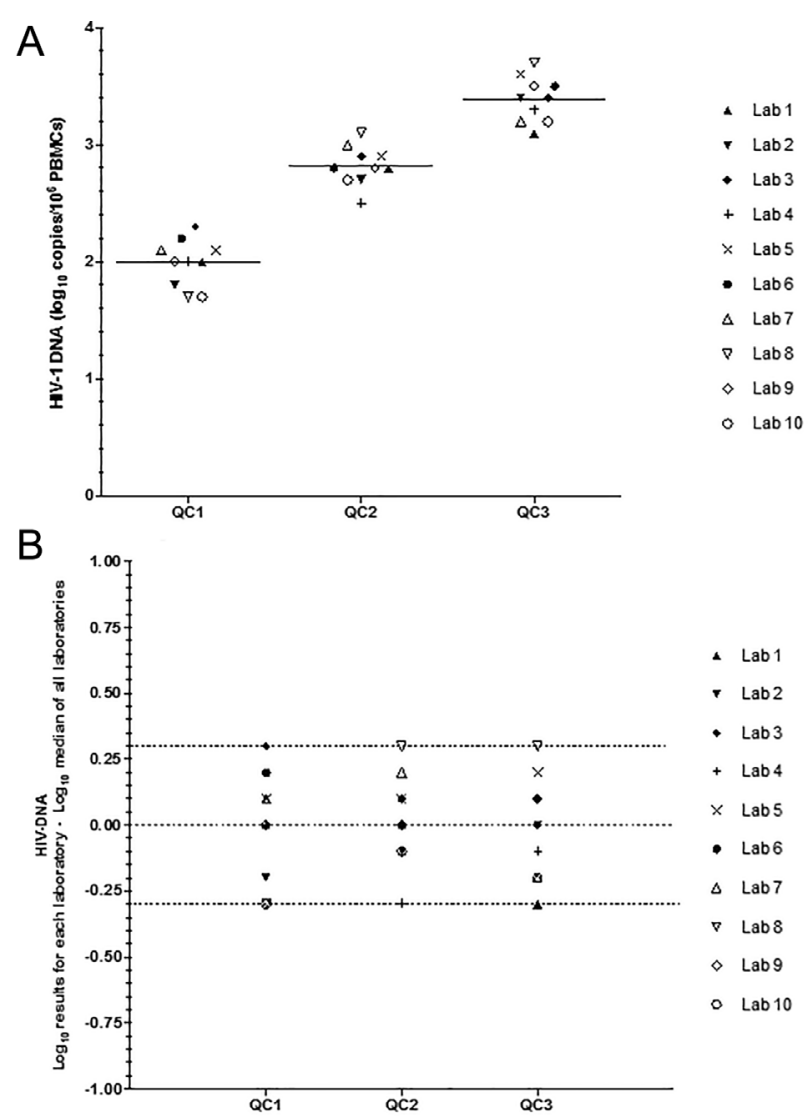

FIGURE 1 Variations of HIV-1 DNA results for the three positive quality controls. (A) HIV-1 DNA results for QC1, QC2, and QC3 in each laboratory. (B) Differences between the result of each laboratory and the median of HIV-DNA load in log copies/million PBMC. One laboratory had detected QC1 but it was not quantifiable (positive $<1.84 \mathrm{log}$ ). This result was considered at the threshold in the figure. Dotted lines indicate median values $\pm 0.3 \mathrm{log}$

on the concentration of total DNA in the extract), results were reproducible within a small range (Fig. 1B).

\section{DISCUSSION}

Several markers have been proposed to estimate the size of HIV reservoir, ${ }^{4}$ but none is definitely considered as the best one. Among them, total cell-associated HIV DNA load is likely to become an increasingly important marker for the management of HIV-1 infection for several reasons: it is easy to perform in parallel to HIV RNA on the same clinical samples, it is clinically relevant at the different stages of HIV infection, ${ }^{4}$ and can be used in research protocols for clinical trials and studies concerning HIV pathogenesis and HIV cure. ${ }^{16-17}$

The reproducibility of a the real-time QPCR LTR HIV-1 DNA assay (Generic HIV DNA CELL, Biocentric) has been previously evaluated in one laboratory for a high-level positive-control sample with mean and standard deviation of $3.30 \log$ copies $/ 10{ }^{6}$ leukocytes and 0.11 log, respectively, and for a moderate-level positive-control sample with $2.40 \log$ copies $/ 10^{6}$ leukocytes and $0.18 \mathrm{log}{ }^{4}$ 
In this study, we describe the first inter-laboratory externalquality control of HIV-1 DNA quantification, implicating ten French virological laboratories,using the same commerciałssay.No such study has ever been performed for the other markers proposed to estimate the HIV reservoir size. This multicenter evaluation showed that there was a good agreement of HIV-1 DNA loads obtained in ten laboratories by using the standardized Generic HIV DNA CELL as'sAylimit of this study is the low number of QCMD samples. However, QCMD is an external international control, bringing the opportunity to evaluate all laboratories in the same conditions. Interestingly, the three samples were at clinically relevant HIV1 DNA levels.All laboratories detect and quantitate HIV-1 DNA loads with a low standard deviation of $0.2 \mathrm{log}$. As indicated in Fig. 1, the differences between median of each quality control and result of each laboratory is lower than $0.5 \mathrm{log}$, as recommended by Kotton et af. ${ }^{0}$ Transplantation 2010. Actually Kotton indicated that the precision of quantitative nucleic acid tests to determine viral load are such that changes in values should be at least threefold $(0.5 \mathrm{log})$ to represent biologically important changés. Whatever the extraction protocol and its variable efficiency, the quality of extracts and the normalization of results by measuring the amount of total DNA explored in the real-time PCR permitted to have comparable results of HIV-DNA expressed per million cells between laboratories. The use of different batches of the Generic HIV DNA CELL assay on different thermocyclers did not compromise the results of this inter-laboratory quality control for HIV-1 DNA quantification. No reference assay is available and commercialized for HIV-1 DNA quantification so we could not perform comparison with one gold standard.

In conclusion, the inter-laboratory reproducibility reported here with this quality control is a key step for future applications in multicenter studies and clinical practice. Interestingly we showed the reproducibility of the standardized quantitative total HIV-1 DNA assay developed by the ANRS working group to quantify the HIV-1 DNA load as a marker of HIV reservoir.

\section{ACKNOWLEDGMENTS}

We thank the QCMD team for preparing the HIV DNA qualitative panel and the ANRS for funding the AC11 working group.

\section{CONFLICTS OF INTEREST}

The authors have no conflicts of interest.

\section{REFERENCES}

1. Churchill MJ, Deeks SG, Margolis DM, Siliciano RF, Swanstrom R. HIV reservoirs: what, where and how to target them. Nat Rev Microbiol. 2016;14:55-60.

2. Eriksson S, Graf EH, Dahl V, et al. Comparative analysis of measures of viral reservoirs in HIV-1 eradication studies. PLoS Pathog. 2013;9: e1003174.

3. Kiselinova M, De Spiegelaere W, Buzon MJ, Malatinkova E, Lichterfeld $\mathrm{M}$, Vandekerckhove L. Integrated and total HIV-1 DNA predict ex vivo viral outgrowth. PLoS Pathog. 2016;12:e1005472.
4. Avettand-Fènoël V, Hocqueloux L, Ghosn J, et al. Total HIV-1 DNA, a marker of viral reservoir dynamics with clinical implications. Clin Microbiol Rev. 2016;29:859-880.

5. Beloukas A, Paraskevis D, Haida C, Sypsa V, Hatzakis A. Development and assessment of a multiplex real-time PCR assay for quantification of human immunodeficiency virus type 1 DNA. J Clin Microbiol. 2009;47:2194-2199.

6. Casabianca A, Gori C, Orlandi C, Forbici F, Federico Perno C, Magnani M. Fast and sensitive quantitative detection of HIV DNA in whole blood leucocytes by SYBR green I real-time PCR assay. Mol Cell Probes. 2007;21:368-378.

7. Avettand-Fènoël $V$, Chaix $M L$, Blanche $S$, et al. LTR real-time PCR for HIV-1 DNA quantitation in blood cells for early diagnosis in infants born to seropositive mothers treated in HAART area (ANRS CO 01). J Med Virol. 2009;81:217-223.

8. Strain MC, Lada SM, Luong T, et al. Highly precise measurement of HIV DNA by droplet digital PCR. PLoS ONE. 2013;8:e55943.

9. De Rossi A, Zanchetta M, Vitone F, et al. Quantitative HIV-1 proviral DNA detection: a multicentre analysis. New Microbiol. 2010;33:293-302.

10. Luzuriaga K, Tabak B, Garber M, et al. HIV type 1 (HIV-1) proviral reservoirs decay continuously under sustained virologic control in HIV-1-infected children who received early treatment. J Infect Dis. 2014;210:1529-1538.

11. Persaud D, Patel K, Karalius B, et al. Influence of age at virologic control on peripheral blood human immunodeficiency virus reservoir size and serostatus in perinatally infected adolescents. JAMA Pediatr. 2014;168:1138-1146.

12. Serrano-Villar S, Sainz T, Ma ZM, et al. Effects of combined CCR5/ integrase inhibitors-based regimen on mucosal immunity in HIVinfected patients naïve to antiretroviral therapy: a pilot randomized trial. PLoS Pathog. 2016;12:e1005381.

13. Avettand-Fenoel V, Prazuck T, Hocqueloux L, et al. HIV-DNA in rectal cells is well correlated with HIV-DNA in blood in different groups of patients, including long-term non-progressors. AIDS. 2008;22:1880-1882.

14. Cockerham LR, Siliciano JD, Sinclair E, et al. CD4+ and CD8+ T cell activation are associated with HIV DNA in resting CD4+ T cells. PLoS ONE. 2014;9:e110731.

15. Chun TW, Murray D, Justement JS, et al. Relationship between residual plasma viremia and the size of HIV proviral DNA reservoirs in infected individuals receiving effective antiretroviral therapy. J Infect Dis. 2011;204:135-138.

16. Darcis G, Kula A, Bouchat S, et al. An in-depth comparison of latencyreversing agent combinations in various in vitro and ex vivo HIV-1 latency models identified bryostatin-1+JQ1 and ingenol-B+JQ1 to potently reactivate viral gene expression. PLoS Pathog. 2015;11:e1005063.

17. Descours B, Petitjean G, López-Zaragoza JL, et al. CD32a is a marker of a CD4 T-cell HIV reservoir harbouring replication-competent proviruses. Nature. 2017;543:564-567.

18. Pasternak AO, Adema KW, Bakker M, et al. Highly sensitive methods based on seminested real-time reverse transcription-PCR for quantitation of human immunodeficiency virus type 1 unspliced and multiply spliced RNA and proviral DNA. J Clin Microbiol. 2008;46:2206-2211.

19. Hong F, Aga E, Cillo AR, et al. Novel assays for measurement of total cellassociated HIV-1 DNA and RNA. J Clin Microbiol. 2016;54:902-911.

20. Kotton CN, Kumar D, Caliendo AM, et al. International consensus guidelines on the management of cytomegalovirus in solid organ transplantation. Transplantation. 2010;89:779-795. 